\title{
ARTYKUŁY
}

Klio. Czasopismo poświęcone dziejom Polski i powszechnym

PL ISSN 1643-8191, t. 27 (4)/2013, s. 3-32

(c) (1) $\Theta$

DOI: http://dx.doi.org/10.12775/KLIO.2013.049

JarosŁaw Pietrzak

(Łódź)

\section{„Cokolwiek serca i afektu Pańskiego mieć dla siebie upraszam"*. Dzieje romansu księcia Janusza Aleksandra Sanguszki zjego sekretarzem Kazimierzem Chylińskim}

\footnotetext{
Tuż w XVII wieku starano się quasi-naukowo wytłumaczyć fenomen „miłości” w oparciu o astrologię i wpływ ciał niebieskich (makrokosmosu) na jednostkę (mikrokosmos). W XVIII wieku uznano, że miłość jest prawem natury, sferą wolności, nieograniczoną ludzkimi zakazami i nakazami. Pogląd ten wyraził m.in. Udalryk Radziwiłł: „Miłość jest ufundowana na prawie przyrodzonym. Wszystko w naturze dowodzi, żeśmy się porodzili dla kochania" ${ }^{1}$. Uzmysławia to, w jak niejednoznacznym świecie rozegrała się miłość zakazana, uznana wówczas zgodnie za przejaw dewiacji i wynaturzenia. Do tej pory w polskiej literaturze historycznej pojawiło się dość niewiele opracowań poświęconych związkom homoseksualnym. Wstępne

* Cytat pochodzi z: Archiwum Państwowe w Krakowie [dalej: APK], Archiwum Sanguszków Teki Arabskie [dalej: AS TA], sygn. 100/2, [K. Chyliński] do [J. A. Sanguszki], b. m., b. d., s. 199 .

${ }^{1}$ Cyt. za: W. Konopczyński, Od Sobieskiego do Kościuszki, Warszaw 1921, s. 188.
} 
studia na ten temat podjął obok Zbigniewa Kuchowicza ${ }^{2}$ także Janusz Tazbir $^{3}$, a w ostatnim czasie do tego grona dołączyli Paweł Fijałkowski ${ }^{4}$, Piotr Oczko $^{5}$ i Wojciech Śmieja ${ }^{6}$. Trzeba w tym miejscu wskazać na niedostatek literatury, co naturalne, traktującej o sprawach wstydliwych, stanowiących tabu, nieakceptowanych społecznie czy po prostu bulwersujących opinię publiczną.

Przed przystąpieniem do właściwego tematu rozważmy kilka kwestii związanych z nomenklaturą pojęć „homoseksualność” i „homoseksualista” oraz założeń metodologicznych. W staropolskim słownictwie znajdujemy bogaty zestaw określeń miłości do osoby tej samej płci. Szeroka paleta wynikała między innymi z wielości przekładów dzieł, przede wszystkim Pisma Świętego, publikowanych przez różnych wydawców: Jakuba Wujka i Leopolita, czy luterańskiego postyllografa, Adama Gdacjusza. Zjawisko uzyskało zatem miana: „aktu sodomskiego”, „bestialstwa”, „paziolubstwa”, „mężczyńskiej psoty”, „mężołożnictwa”, „tureckiego niewstydu”, „mężczyzny z mężczyzną brzydliwego bawienia się”, „paskudnego wschodniego narowu”, „sodomii”, „grzechu sodomskiego”, „samcołożnictwa”. Osoba żywiąca skłonności homoseksualne nazywana była „samcołożnikiem”, „mężołożnikiem”, „gomorczykiem”, „sodomitą”, „gamratem nieczystym”, „niewieściuchem”, a także „armafrodytem”. Niektóre z tych pojęć miały jednak szerokie pole semantyczne, zależne od kontekstu całości tekstu. Dla

2 Z. Kuchowicz, Mitość staropolska. Wzory - uczuciowość - obyczaje erotyczne XVI-XVIII wieku, Łódź 1982; idem, Cztowiek polskiego baroku, Łódź 1991, s. 318-321; idem, Spoteczne konsekwencje postępującej degeneracji możnowtadztwa polskiego w XVII-XVIII wieku, „Kwartalnik Historyczny” 1969, R. 29, z. 1, s. 31-42.

3 J. Tazbir, Staropolskie dewiacje obyczajowe, „Przegląd Humanistyczny” 1985, R. 19, nr 7/8 (238/239), s. 1-13.

${ }^{4}$ P. Fijałkowski, Homoseksualizm. Wykluczenie - transgresja - akceptacja, Warszawa 2000.

5 P. Oczko, Dlaczego nie chce pisać o staropolskich samcotożnikach? Przyczynek do „archeologii” gay studies w Polsce, „Teksty Drugie” 2008, t. 5, s. 32-50; P. Oczko, T. Nastalczuk, Homoseksualność staropolska. Przyczynek do badań, Kraków 2012.

${ }^{6}$ W. Śmieja, Historie (homo)seksualności od studiów gejowsko-lesbijskich do queer studies, „Przegląd Historyczny” 2012, t. 53, z. 1, s. 129-151.

7 Stosowane przez autorów odmiany analizuje szczegółowo Janusz Tazbir w swoim artykule, zob.: J. Tazbir, Staropolskie..., s. 1-3. 
przykładu „sodomczyk” oznaczał nie tylko homoseksualistę, ale też onanistę, zoofila czy człowieka uprawiającego seks analny z kobietą. Podobnie definicja „armafrodyt” odnosiła się do homoseksualisty oraz osoby posiadającej obojnacze cechy płciowe ${ }^{8}$. W tej sytuacji analiza pojedynczego utworu stanowi jedyny klucz do prawidłowego odczytania intencji autora. John Boswell postuluje, by używać terminologii „gej”, „lesbijka”, ponieważ terminy „homoseksualizm” i „homoseksualista” narodziły się dopiero w XIX wieku. Zdaniem badacza posługiwanie się tego typu terminami w niczym nie narusza godności osób, zaakceptowały one bowiem swoją tożsamość i ma to charakter afirmujący, a nie piętnujący?.

W ostatnich latach na łamach „Tekstów Drugich” Piotr Oczko zainicjował spór, odwołując się do stwierdzenia Zbigniewa Kuchowicza, dotyczący skali i natężenia zjawiska homoseksualności w Rzeczypospolitej na przestrzeni XVI-XVIII wieku. Skrytykował on pogląd historyka, że zjawisko miłości homoseksualnej w Polsce wcale nie występowało ${ }^{10}$. Dodajmy, że Kuchowicz swoją tezę oparł na przekazie niemieckiego lekarza Kuscha:

Co się tyczy pederastii, cieszącej się takim powodzeniem u sąsiadów Polski, trzeba na chwałę Polakom powiedzieć, że jest ona tutaj nieznana i prawie tak samo wzgardzona jak w Angliii ${ }^{11}$.

Krytyk w swym ad vocem uznał w sposób bezsprzeczny i niemal dogmatyczny, że liczebność osób homoseksualnych w danym społeczeństwie, niezależnie od epoki i warunków, zawsze waha się od 2 do $7 \%$ populacji ludzkiej ${ }^{12}$.

W artykule podjęta zostanie próba zajęcia własnego stanowiska w tej polemice. Oczywiście nie możemy zaufać sądowi Zbigniewa Kuchowicza, ponieważ wówczas badania podjęte w pracy byłyby bezzasadne, dlatego

8 P. Oczko, op. cit., s. 45.

9 J. Boswell, Chrześcijaństwo, tolerancja spoteczna i homoseksualność, Kraków 2006, s. $51-67$.

10 Z. Kuchowicz, Mitość staropolska..., s. 444.

11 J. J. Kusch, Wizerunek narodu polskiego, [w:] Polska stanistawowska w oczach cudzoziemców, t. 2, wyd. W. Zawadzki, Warszawa 1963, s. 291.

12 P. Oczko, op. cit., s. 38; P. Oczko, T. Nastalczuk, op. cit., s. 60-61. 
przyjmujemy, że opieranie się na pojedynczym przekazie nie dowodzi prawie niczego. Z drugiej strony nie możemy zaufać Oczce, który nie popiera danych statystycznych gruntowniejszymi badaniami, nie podaje też podstawy źródłowej. Kompromisowo można jednak przyjąć, że liczba osób homoseksualnych w społeczeństwach europejskich, w tym i polskim, nie była duża. Pogląd taki akceptuje Andrzej Wyrobisz, zauważając, że skala zjawiska na przestrzeni dziejów i w różnych środowiskach jest elementem stałym, ale niszowym, ograniczonym ${ }^{13}$.

Marginalizacja orientacji homoseksualnej w czasach staropolskich wynikała z silnego wpływu licznych prądów ideowych, w tym religii. W czasach polskiego odrodzenia popularność zyskały poglądy greckiego filozofa Plutarcha, który związek kobiety i mężczyzny uznawał za jedyny i święty. Myśl ta zdyskontowała koncepcję miłości platońskiej oznaczającą wyłącznie miłość w obrębie płci męskiej ${ }^{14}$. Zakaz obcowania przedstawicieli tej samej płci był silnie zakorzeniony w kulturze judeochrześcijańskiej. Jego złamanie oznaczało wystąpienie przeciw woli Bożej i pogrążenie się w religijnej nieczystości. Wspierał się on na fundamencie i autorytecie Pisma Świętego, jako kanonu praw sankcjonujących ludzkie występki. Liczne passusy Starego i Nowego Testamentu piętnują zachowania i skłonności homoseksualne. Najczęściej wymieniany jest obraz Sodomy i Gomory, miast symbolizujących siedliska występku i grzechu. Kara, która wymierzona została mieszkańcom, miała ilustrować sprawiedliwość Bożą i przestrzegać przed jej następstwami. Motyw Sodomy został wykorzystany później w dziełach apokryficznych na określenie zagłady ludzkości w dniach ostatecznych ${ }^{15}$. Biblia jasno wyraża się o homoseksualizmie:

Kto obcuje cieleśnie z mężczyzną, tak jak obcuje się z kobietą, wraz z nim dopuszcza się obrzydliwości; obaj muszą ponieść śmierć, bo ściągnęli na siebie ten wyrok $^{16}$.

13 A. Wyrobisz, Rodzina w mieście doby przedprzemystowej a życie gospodarcze. Przeglad badań i problemów, „Przegląd Historyczny” 1986, t. 77, z. 2, s. 312.

14 Z. Kuchowicz, Mitość staropolska..., s. 102.

15 P. Fijałkowski, op. cit., s. 91.

16 Stary Testament. Księga Kaptańska, 20,13, [w:] Pismo Święte Stary i Nowy Testament, wyd. M. Petera, M. Wolniewicz, Poznań 2007, s. 148. 
Homoseksualizm został naznaczony grzechem, ponieważ jego konsekwencją było zerwanie przymierza człowieka z Bogiem. W ujęciu nowotestamentowym rozbrat pomiędzy człowiekiem a Bogiem wynikający z popełnionego grzechu równał się potępieniu i zagrodzeniu duszy wejścia do raju:

Królestwa Bożego nie osiągną rozpustnicy, bałwochwalcy i cudzołożnicy, ludzie nieumiejący się oprzeć rozkoszom i mężczyźni współżyjący ze sobą ${ }^{17}$

- grzmi święty Paweł. Kultura staropolska, która wyrosła między innymi na korzeniu chrześcijańskim, w której głos Kościoła był decydujący, akceptowała w pełni tę naukę. „Nieprzystojne amory” naruszały sakramentalną zasadę małżeństwa, czym gwałciły chrześcijańską moralność ${ }^{18}$. Dla religijnych piewców homoseksualista oznaczał człowieka do szczętu złego, nieumiejącego panować nad swymi emocjami i uczuciami. Podobną postawę zajmowały Kościoły reformowane, kierujące się zasadą moralnej sanacji, praktykowanej skromności i czystości w życiu codziennym. Pastor Adam Gdacjusz pisał:

Sodomia jest to haniebna nieczystość [...], przed którą aniołowie uciekają, którą diabli widząc oczy zawierają, którą mężczyźni z mężczyznami płodzą ${ }^{19}$.

Homoseksualność w czasach staropolskich była synonimem patologii, zniewieścienia i upadku obyczajów w narodzie. Prawdopodobnie w tym można upatrywać popularności tego określenia wśród repertuaru obelg stosowanych w komunikacji społecznej. Wynikało to z faktu nieformalnej reakcji na dewiację bez uciekania się do represji ${ }^{20}$. Technika dyskredytacji

17 Nowy Testament, I List św. Pawta do Koryntian, 6,9 [w:] ibidem, s. 1622.

${ }_{18}$ Inne stanowisko zajmuje w tej sprawie John Boswell, powołując się na skłonności króla Dawida do Jonatana wyrażone w jednym z psalmów, który uznaje za przykład poezji homoerotycznej, zob.: J. Boswell, op. cit., s. 59-156.

19 A. Gdacjusz, O pańskim albo rycerskim stanie dyszkurs, [w:] Wybór pism, wyd. H. Borek, J. Zaremba, Warszawa-Wrocław 1969, s. 402.

20 A. Perzanowski, Odmieńcy. Antropologiczne studium dewiacji, Warszawa 2009, s. $30-31$. 
obyczajowej posługiwała się przedstawianiem opinii publicznej pikantnych ciekawostek i niecodziennych zachowań z życia atakowanego, które nie mieściły się w ramach konwenansu i przyjętej tradycji. Ich rzekomy, niczym przecież niepotwierdzony charakter, prowadził do wywołania ogólnej konsternacji, skandalu, a nawet owocował wrogością ${ }^{21}$.

Posądzenie o utrzymywanie kontaktów z tą samą płcią funkcjonowało jako oszczerstwo na arenie polityki krajowej. Homoseksualność imputowano Michałowi Korybutowi Wiśniowieckiemu i królewiczowi Jakubowi Ludwikowi Sobieskiemu. Nie miejsce tu, aby przedstawiać mechanizm kreacji i arsenał środków propagandowych, za pomocą których stworzono fałszywy obraz tych postaci ${ }^{22}$. Warto jednak przywołać kilka bardziej ogólnych uwag. W Polsce, gdzie życie publiczne opierało się na instytucjach sejmików, sejmu, sądów ziemskich, grodzkich itd., na których wypowiadali się tylko mężczyźni, posądzenie o homoseksualizm było bronią służącą ekskluzji, czyli wykluczeniu z grona decydentów. „Samcołożnictwo” było argumentem ad personam w dyskusji politycznej, plotką strojącą się w kostium niepodważalnej prawdy, potęgującą ciężar zarzutów. Zarówno Michał Korybut Wiśniowiecki, jak i Jakub Ludwik Sobieski odbiegali od wyobrażeń ukształtowanych przez sarmacki wzorzec kulturowy. Malkontenci wypominali królowi „noszenie się po francusku” i szminkowanie ust

${ }_{21}$ M. Karwat, O ztośliwej dyskredytacji. Manipulowanie wizerunkiem przeciwnika, Warszawa 2006, s. 234-235.

${ }^{22}$ Więcej na temat „czarnych legend” Michała Korybuta Wiśniowieckiego, zob.: Exorbitantie ad correcturam Seymu Anni 1672, [w:] Pisma do wieku i spraw Jana Trzeciego, [dalej: Pisma do wieku...], t. 1, cz. 2, Kraków 1898, s. 994; A. Przyboś, Michat Korybut Wiśniowiecki 1640-1673, Kraków 2007, s. 92-93 oraz Jakuba Ludwika Sobieskiego, zob.: Biblioteka Polskiej Akademii Umiejętności - Polskiej Akademii Nauk w Krakowie, sygn. 984, Respons z pewnego sejmiku realtiones po zerwanej konwokacji na list Jegomości Xdza Dąmbskiego biskupa kujawskiego, k. 296-297; K. Piwarski, Królewicz Jakub Sobieski w Otawie, Kraków 1939, s. 15; Z. Kuchowicz, Spoteczne konsekwencje..., s. 29; E. Rostworowski, Zdrowie i niezdrowie polskich magnatów XVI-XVII wieku, „Kwartalnik Historyczny" 1969, R. 76, z. 4, s. 882; A. Skrzypietz, Królewscy synowie-Jakub, Aleksander i Konstanty Sobiescy, Katowice 2011, s. 260-316. 
z obrazą Bożą, czym drogi czas consumitur i authoritas Pana vilescit apud cives, owa codzienna igluvies nie tylko Principi, ale i ordynaryjnemu nieprzystojna człowiekowi $^{23}$.

Podobne głosy podnoszono wobec syna Jana III, człowieka

wzrostu średniego, czarnych włosów, bardzo szczupłego, z niewieścim głosem i twarzą suchotnika [...] Król go nie kocha, dlatego że jest francuzikiem zepsutym przez płeć piękną i niezdolny do stanu rycerskiego ${ }^{24}$,

a jak doda sekretarz posła francuskiego, Melchiora de Polignaca:

nie odznacza się piękną postawą. Ma kobiece maniery i mówi falsetem. Choć nie jest piękny, widziałem często muszki na jego twarzy"25.

Powierzchowność obu kłóciła się z przyjętym modelem szlachcica, którego winno cechować smagłe lico, wyniesione czoło, gęsty wąs, pewny chód, barczystość i znakomita tusza. Taka aparycja i dostojna fizyczność oprawiona w strój narodowy, zbroję i pasy trwały w umysłach jako wzór idealnego mężczyzny ${ }^{26}$. Popularność mody francuskiej, która święciła swe triumfy w drugiej połowie XVII wieku, sprawiła, że zarówno Michał Korybut, jak i Jakub Ludwik wykorzystali jej zdobycze dla zamaskowania własnych defektów ciała: ospowatości twarzy, niewielkiego wzrostu czy skoliozy kręgosłupa ${ }^{27}$. Wyróżniający się na tle zuniformizowanej strojem szlachty byli wyzywani od „małp” i nie stanowili indywidualności godnych naśladowania. Oryginalność w ich przypadku była raczej określeniem pejoratyw-

${ }^{23}$ Exorbitantie..., [w:] Pisma do wieku..., t. 1, cz. 2, Kraków 1898, s. 994.

24 [J. Ch. Faggiuoli], Diariusz podróży do Polski, wyjęty z pamiętników Jana Chrzciciela Faggiuoli, „Czas. Dodatek Miesięczny” 1858, R. 3, t. 12, wyd. F. Kluczycki, s. 249.

${ }_{25}$ M. de Mongrillon, Pamiętnik sekretarza ambasady francuskiej $w$ Polsce pod koniec panowania Jana III oraz bezkrólewia i wolnej elekcji po jego zgonie (1694-1698), wyd. Ł. Częścik, Wrocław-Warszawa-Kraków 1982, s. 50-51.

26 Z. Kuchowicz, Mitość staropolska..., s. 248-249.

27 I. Czamańska, Wiśniowieccy. Monografia rodu, Poznań 2007, s. 250-251, 263; A. Skrzypietz, Królewscy synowie..., s. 103; P. Oczko, T. Nastalczuk, op. cit., s. 216-224. 
nym niż miłym komplementem. Posiadający niezwykłą wiedzę w zakresie wielu przedmiotów i znajomość języków, nie byli też powszechnie uznawanymi bellatorami, czyli osobami znającymi wojskowe rzemiosło i wyróżniającymi się dowódcami. Z powodu licznych wojen i batalii toczonych przez Rzeczpospolitą w XVI i XVII wieku, naród szlachecki raczył widzieć w monarsze emanację Stefana Batorego czy Jana III Sobieskiego, których czyny ustrzegły kraj przed niebezpieczeństwem i zapewniły spokój na granicach państwa, a tym samym - w jego dobrach. Przypadki króla-rodaka i królewskiego syna stanowią kazusy, w których homoseksualność wykorzystano do dyskredytacji obyczajowej, przypięcia „etykietki”, delegitymizacji wpływów obu mężczyzn ${ }^{28}$.

Nazywanie kontaktów homoseksualnych „aktami sodomskimi” lub „praktyką sodomiczną”, zdaniem Piotra Oczki, z góry zakłada potępienie i naraża na drwinę. Homoseksualność w epoce staropolskiej kojarzyła się z dewiacją, czyli zerwaniem z ustalonymi normami obyczajowymi. Trzeba jednak zastrzec, że na taki sąd wpłynęło postrzeganie „homoseksualizmu” wyłącznie jako aktu fizycznego, bez analizy jego psychoemocjonalnych uwarunkowań. Wspomniani historycy dysponowali okrojoną, często powtarzającą się bazą źródłową, co stanowiło barierę dla rzetelności i nowego ujęcia zjawiska. Zapomnieli przy tym o zwróceniu uwagi na warunki, w których egzystowali homoseksualiści, przez co nie udało się przekazać pełnej informacji o podjętym problemie badawczym. Nie powstało dotąd opracowanie pokazujące, czy i jak homoseksualiści mogli wyrażać swoje uczucia związane ze stanem zakochana, pożądaniem i w końcu spełnioną miłością. Na pytanie postawione przez Piotra Seweryna Rosoła (,,jakiej historii potrzebują homoseksualiści?”) można odpowiedzieć, że winna ona wpisywać się w nurt tzw. nowej humanistyki, promującej nie tylko interdyscyplinarność badań, ale podjęcie dyskursu w sprawie „odmienności” etnicznej, religijnej oraz seksualnej ${ }^{29}$. Badania marginesu i patologii społecznej mają swoje korzenie o ustalonych i trwałych podstawach metodologicznych, wspomnijmy per exemplum prace Bronisława Geremka. Jestem

${ }_{28}$ M. Karwat, op. cit., s. 108-109, 179-181, 226-227.

29 P. S. Rosól, Masochistyczna homohistoria. Lektura berlinskiego Schwules Museum, „Teksty Drugie” 2008, t. 5, s. 60-62. 
przekonany, że rewindykacyjny i insurekcyjny styl piśmiennictwa nie naruszy gmachu Historii, jeśli tylko utrzymana zostanie zasada dogłębnych badań źródłowych przy umiejętnej interpretacji zebranego materiału. Ważne wydaje się również zachowanie umiarkowania względem przekazu i emocji, jakie tenże przekaz wywołuje ${ }^{30}$.

Piotra Oczko postuluje i wręcz domaga się nowego odczytania epistolografii, sylw i poezji staropolskiej. W swym tekście rzuca badaczom wyzwanie i zachętę w słowach:

Chciałbym dowiedzieć się czegoś więcej o Januszu Aleksandrze Sanguszce i Karolu Szydłowskim, który „władał sercem jego”, o uwięzionym w gdańskim cekhauzie Chylińskim (i o tym, czy Sanguszko bolał po jego stracie) ${ }^{31}$.

Należy jeszcze zastrzec, że wstęp ten ma służyć lepszemu zrozumieniu przestrzeni, w której doszło do romansu. Mam nadzieję, że ten artykuł rozwieje wiele wątpliwości i wyjdzie naprzeciw oczekiwaniom cytowanego autora.

Janusza Aleksandra Sanguszkę i Kazimierza Chylińskiego, mimo że obaj byli szlachcicami, różniła przynależność warstwowa w obrębie stanu. Pierwszy należał do magnaterii, jako że spełniał wszystkie warunki ku temu podane przez Adama Kerstena ${ }^{32}$. Syn Pawła Karola Sanguszki, marszałka nadwornego litewskiego, i Marianny z Lubomirskich miał pełne prawo tytułować się księciem. W żyłach Janusza Aleksandra płynęła krew kniaziowskiego rodu Sanguszków linii kowelskiej, która swe pochodzenie wywodziła od Giedymina. Ród, który początkowo nie posiadał wielkiego majątku ani znaczenia, w drugiej połowie XVII wieku począł wzrastać dzięki koligacjom z najznamienitszymi rodami litewskimi, m.in. z Sapiehami i Radziwiłła$\mathrm{mi}^{33}$. Matczyne koligacje były jeszcze świetniejsze. Matka Janusza, Marian-

30 P. Oczko, T. Nastalczuk, op. cit., s. 72-91, 105-118.

31 P. Oczko, op. cit., s. 41.

32 A. Kersten, Warstwa magnacka - kryterium przynależności, [w:] Magnateria polska, jako warstwa spoteczna, red. W. Czapliński, A. Kersten, Toruń 1974, s. 8-12.

33 Paweł Karol był drugim, po Kazimierzu Antonim (zm. 1706), synem starosty suraskiego, Hieronima Sanguszki, oraz Konstancji z Sapiehów, córki hetmana wielkiego litew- 
na, była córką Teofili Ludwiki z Ostrogskich-Zasławskich, primo voto Wiśniowieckiej, secundo voto Lubomirskiej, a tym samym wnuczką Katarzyny z Sobieskich primo voto Ostrogskiej-Zasławskiej, secundo voto Radziwiłłowej, siostry Jana III Sobieskiego. Pokrewieństwo po kądzieli wiązało księcia nie tylko ze wspaniałymi i najbogatszymi rodami kniaziowskimi (Ostrogscy-Zasławscy, Wiśniowieccy) i hrabiowskimi (Lubomirscy), ale przede wszystkimi z samym monarchą, który do historii przeszedł jako pogromca Turków spod Wiednia i obrońca chrześcijaństwa. Wspaniałości parantelom dodawał fakt, że siostra matki, Teresa Lubomirska (zm. 1712), była żoną późniejszego palatyna reńskiego (od 1716 r.) Karola Filipa Neuburga, pierwszego męża Ludwiki Karoliny Radziwiłłówny. Tym samym książę-ordynat mógł szczycić się powinowactwem nie tylko z polską magnaterią, ale domami panującymi Europy. Więzy krwi spowodowały również, że Janusz Aleksander posiadał ogromne latyfundium, stanowiące przedmiot zazdrości niejednego magnata - ordynację ostrogską. Latyfundium, które w okresie swego największego rozkwitu liczyło 23 miasta i 400 wsi, aczkolwiek w omawianym okresie już uszczuplone (w spisach dóbr ordynackich pochodzących z 1753 r. odnotowano bowiem 17 miast i 357 wsi), nadal przynosiło znaczne zyski do skarbu książęcego. Odnotujmy jednak, że dobra odziedziczone po Mariannie i zmarłym bezpotomnie stryju Aleksandrze Dominiku Lubomirskim, staroście sandomierskim, znalazły się początkowo w zarządzie ojca, Pawła Karola Sanguszki. Dopiero na mocy umowy z 12 grudnia 1738 roku zostały one przekazane Januszowi Aleksandrowi w administrację wraz ze starostwem czerkaskim i kamienieckim ${ }^{34}$. Nie

skiego Pawła Jana Sapiehy. Siostry Pawła Karola: Anna Katarzyna w 1692 roku poślubiła Karola Stanisława Radziwiłła, syna Michała Kazimierza i Katarzyny z Sobieskich, Krystyna wyszła za Władysława Józefa Sapiehę, wojewodę mińskiego. O karierze Pawła Karola zob.: J. Staszewski, August II Mocny, Wrocław 1998, s. 257, 264; A. J. Baranowski, Między Księstwem Litewskim a Koroną Polska. Wzrost roli Sanguszków w Rzeczypospolitej na początku XVIII wieku, [w:] Wokót Sanguszków. Dzieje - sztuka - kultura. Materiaty I Ogólnopolskiej Konferencji Naukowej 29-30 czerwca 2006 roku, Tarnów 2007, s. 39-41; A. Jakuboszczak, Sarmacka dama. Barbara Sanguszkowa (1718-1791) i jej salon towarzyski, Poznań 2008, s. 29.

34 Marianna z Lubomirskich na mocy umów z 1710 i 1711 przekazała Pawłowi Karolowi klucze kijański, jakubowicki wraz z Lewartowem w województwie lubelskim, ostrowiecki i ćmielowski w województwie sandomierskim. Po śmierci swej i brata, Aleksandra 
zmienia to faktu, że Sanguszkowie trzymali dobra ordynackie niezgodnie ze statusem kasztelana krakowskiego - Janusza Ostrogskiego z 1609 roku, jeżeli weźmie się pod uwagę przeprowadzone w latach 1674-1678 uzgodnienia $^{35}$. Osobną, lecz nie mniej ważną kwestię stanowią urzędy pełnione przez księcia. Najpierw, w 1735 roku, został obdarzony miecznikostwem litewskim. W 1750 roku August III powierzył marszałkostwo nadworne litewskie, które przekazał za zgodą królewską w 1760 roku przyrodniemu bratu, Józefowi Paulinowi ${ }^{36}$. Dodać do tego należy wybór z powiatu krzemienieckiego na deputata do Trybunału Koronnego w Piotrkowie, a potem na jego marszałka. Brak zainteresowania przebiegiem obrad i rzadki udział w sesjach nie pozwalają zaliczyć Janusza Aleksandra do aktywnych uczestników posiedzeń. Niewyróżniający się niczym w życiu publicznym, przeszedł do historii jako człowiek odpowiedzialny za „rozbiór” dóbr ostrogskich na mocy tak zwanej transakcji kolbuszowskiej z grudnia 1753 roku. Sławę birbanta, awanturnika i lekkoducha łączył z ogromną pobożnością i opieką nad fundacjami bernardynów i jezuitów w Cudnowie i Ilińcu. Podkreślić należy doskonałą edukację, którą odebrał nie tylko w domu, ale przede wszystkim podczas grand tour trwającej w latach $1730-1732$ po krajach Rzeszy, w czasie której przebywał w Dreźnie ${ }^{37}$.

Dominika, Paweł Karol wszedł w posiadanie dóbr ordynackich. Dodatkowo, w 1738 roku, Janusz Aleksander zrzekł się kluczy jakubowskiego, kijańskiego, łąckiego i lewartowskiego (lubartowskiego), hrabstwa tarnowskiego, Zasławszczyzny i dóbr węgierskich (Makowica i Budzimierz) w zamian za wymienione starostwa i rekompensatę pieniężną w wysokości 2150000 złotych. Więcej zob.: T. Zielińska, Magnateria polska epoki saskiej, WrocławWarszawa-Kraków 1977, s. 12; W. Berkowski, Dziatalność gospodarcza Sanguszków na Wotyniu w XVIII i XIX wieku. Latyfundium stawuckie, [w:] Wokót Sanguszków..., s. 47-48.

35 Więcej na ten temat: Akta publiczne do interessu Ordynacyi ostrogskiey należace, Warszawa 1746; J. Pietrzak, Walka Katarzyny z Sobieskich Radziwittowej o dobra ordynacji Ostrogskich w latach 1673-1678. Przyczynek do historii rozpadu latyfundium, „Czasy Nowożytne" 2013, t. 26, s. 53-74.

36 R. Marcinek, Sanguszko Janusz Aleksander, [w:] Polski Stownik Biograficzny [dalej: PSB], Wrocław-Warszawa-Kraków 1993, s. 490-491.

37 APK, Archiwum Sanguszków ze Sławuty, sygn. 431, Wyjątki z różnych historii z 1720; sygn. 493, Opisanie podróży JO. Xcia Jmci ordynata ostrogskiego z Klobuszowej die 16 aprilis 1730 anno do Saksonii, k. 1-19; Biblioteka Polskiej Akademii UmiejętnościPolskiej Akademii Nauk w Krakowie, sygn. 985; A. Jakuboszczak, op. cit., s. 31 
Zupełnie inaczej prezentowało się pochodzenie i przebieg kariery Kazimierza Chylińskiego. Nie dysponujemy dokładnym wywodem jego przodków tytułujących się „de Chylin Chylińscy”. Kasper Niesiecki wspomina, że Chylińscy herbu Jastrzębiec związani byli z Mazowszem ${ }^{38}$. Nie wiadomo nawet, czy Kazimierz Chyliński miał jakiekolwiek związki rodzinne z Chylińskimi zamieszkałymi w Wielkopolsce, a tym bardziej z żyjącym w tym samym czasie franciszkaninem, obecnie świętym Rafałem Chylińskim ${ }^{39}$. Wiarygodniejsze dane prezentuje Wojciech Wielądek, którego wywody zacytował Niesiecki. Rodzicami ojca Jana Józefa, cześnika latyczowskiego, byli, zdaniem staropolskiego genealoga, Jan Chyliński i Eufrozyna ze Świeradowskich, a dziadkami - Piotr Chyliński i Elżbieta z Męcińskich. U pnia tego drzewa genealogicznego na podstawie dokumentu z 1782 roku Wielądek umieścił Stanisława Chylińskiego, chorążego chełmskiego, trzymającego wraz z żoną Katarzyną z Olędzkich dobra Chylin w ziemi chełmskiej oraz Latyczyn w województwie bełskim ${ }^{40}$. Jeszcze bardziej rozbudowane wiadomości odnajdujemy w liście samego Kazimierza Chylińskiego. W obawie przed zbliżającym się procesem i podejrzeniem, że Paweł Karol zechce „nagonic” jego szlachectwo, poprosił brata o apel do rodziny Chylińskich i powinowatych:

Wyrażam tu do nas należących najpierwej JMściów Panów Chylińskich braci stryjecznych sześciu, których zna bardzo dobrze J. O. JMśc Pan kanclerz W. Lit. [tj. Jan Fryderyk Sapieha - J. P.], którzy mieszkają niedaleko w Kownie w Litwie. Jeden zaś JMśc Pan Wojciech rezyduje niedaleko Błot w Litwie, drugi mieszka niedaleko Lubomla na imię mu Stanisław, dwóch w krakowskim, dwóch w ziemi stężyckiej do tego imienia należą ci Ich Mściowie, którzy się z Chylińskich rodzą jako to Jmście Panowie Kulikowscy, braci czterech ci służą w regimentach cesarskich, jeden już jest u JMści Pana Chylińskiego w sieradzkim bo i tam jest jeden JMśc Pan Chyliński Piotr, nasz stryj po tym należę Jmści Panowie Sędzimirowie, sędzia stężycki i Jmści, potym Jmść PP. Głęboccy, w ziemi stężyckiej, po tym Ich

38 K. Niesiecki, Herbarz polski, wyd. J. N. Bobrowicz, t. 3, Lipsk 1839, s. 102.

39 L. J. Bernatek, Btogostawiony Rafat Chyliński z Eagiewnik, Niepokalanów 1991, s. 9-13; idem, Ojciec Rafat Chyliński 1694-1741, Łódź 1991, s. 11-17.

${ }^{40}$ K. Niesiecki, op. cit., t. 3, s. 102; Urzędnicy województwa betskiego i ziemi chetmskiej XIV-XVIII wieku. Spis, opr. H. Gmiterek, R. Szczygieł, red. A. Gąsiorowski, Kórnik 1992, s. 199. 
Mście PP. Poniatowscy którzy są i w sandomierskiej ziemi po tym PP. Milewscy, Jmście Panowie Gaworzewscy Zażewscy, Szkutleccy, Żebrowscy, Marchoccy, Kołaczkowscy, JMść pisarz grodzki buski teraźniejszy ${ }^{41}$.

Reasumując, Kazimierz Chyliński należał do gałęzi rodu osiadłej na Rusi, która w wyniku stopniowego rozrodzenia rozpierzchła się po Litwie, Małopolsce, ziemi sieradzkiej i tam osiadła. Syn Jana Józefa należał wraz ze swoim rodzeństwem - braćmi Julianem i Stanisławem oraz siostrami Katarzyną Kołaczkowską i Zofią primo voto Marchocką, secundo voto Koronacką - do średniej, jeśli nie zubożałej szlachty. Dzieciństwo spędził w rodzinnych Rudniczkach w ziemi sandomierskiej, niedaleko Połańca ${ }^{42}$. Kazimierz musiał odebrać wykształcenie prawnicze, ponieważ nazywany był praktykiem sądowym, czyli biegłym w zakresie polskiego prawa ziemskiego i kryminalnego. W 1743 roku, z woli chorążego koronnego i starosty oświęcimskiego i wąwolnickiego, Chyliński został mianowany subdelegatem księstwa oświęcimskiego ${ }^{43}$. Nie wiadomo, kiedy został mianowany stolnikiem łomżyńskim. Owiany tajemnicą pozostaje również moment spotkania Chylińskiego z księciem Januszem Aleksandrem oraz przejścia na jego służbę. Możemy założyć, że nastąpiło to znacznie wcześniej niż w przedziale pomiędzy 1743 a 1744 rokiem, zapewne już w latach 1737-1740, o czym może świadczyć zapis dokumentowy, obligujący Chylińskiego do wydania sumy 36000 złotych na zakup karabelki powlekanej złotem, oraz list Stanisława Dzianota $^{44}$. Wiadomo, że działalność Chylińskiego rozwinęła się w 1745

41 APK, AS TA, sygn. 42/7, K. Chyliński do [J. Chylińskiego], b. m. i d., s. 15-16.

42 O ich zasiedzeniu tam świadczą akty chrztów kolejnych członków rodu, wydawane przez prepozytów połanieckich, Bartłomieja Jana Sulikowskiego w 1707 i Ignacego Duchnowskiego w 1748 roku., por.: APK, AS TA, sygn. 100/22, s. 69, 163, 167.

43 APK, AS TA, sygn. 100/25, A. Małachowski do K. Chylińskiego, Lublin, 12 VII 1743 , s. 7.

${ }^{44}$ APK, AS TA, sygn. 42/7, J. A. Sanguszko do K. Chylińskiego, Dubno, 18 XI 1740, s. 9; sygn. 263/4, S. Dzianot do K. Chylińskiego, Szczyglice, 14 XI 1737, s. 169-172. Sanguszko wykorzystywał Chylińskiego, od marca do listopada 1740 roku, w charakterze pośrednika handlowego w sprawie zakupu precjozów u jubilera gliniańskiego - Hirsza i wypłaty należności. Sprawa ta trwała do 1747 roku, vide: APK, AS TA, sygn. 42/7, s. 23, 27, 33; sygn. 100/22, s. 151, 187. 
roku i trwała do 1749 roku, to jest czasu uwięzienia ${ }^{45}$. Niewykluczone, że pierwsze spotkanie mogło nastąpić przy okazji oddania Kazimierza na dwór Sanguszki. Rodzice, którzy zapewne należeli do szlachty zbiedniałej, mieli ambicje, by ich syn zyskał szkołę i wszedł w krąg dorosłego społeczeństwa bogatszych i znaczniejszych wielmożów. Dwór pański był - tak jak dwór królewski - szkołą polerującą obyczaje, zmuszającą do ciągłej gotowości w służbie nauczyciela, czyli magnata.

Książęcy sługa i kochanek w jednej osobie w niedługim czasie zyskał wiele praw i przywilejów. Rozpoczynał karierę w charakterze plenipotenta prawnego księcia i jego małżonki Konstancji z Denhoffów Sanguszkowej w Trybunale Koronnym, sądach ziemskich i grodzkich: łuckim, krzemienieckim, owruckim, włodzimierskim, winnickim, sandomierskim, nowomiejskim i sądeckim ${ }^{46}$. Nie była to eksponowana funkcja, ponieważ magnat posiadał wielu takich przedstawicieli. Oznacza to, że dopiero po 1746 roku zyskał większe wpływy i awansował w strukturach dworskich. Doświadczenie pozwalało Chylińskiemu sprawować pieczę nad książęcą szkatułą. Występował jako pośrednik niespłaconych długów Janusza Aleksandra względem przeróżnych wierzycieli ${ }^{47}$. Zgodnie z zarzutami przedstawionymi mu w memoriale najprawdopodobniej z 1749 roku:

I jako do respektów Pańskich był Pan Chyliński najpierwszy, tak wszyscy dworscy i ekonomostwo więcej sobie jego poważając rozkazy niż J. O. Xcia Jmci Miecznika Pana [tj. Janusza Aleksandra ks. Sanguszki - przyp. J. P] swojego na nie ważyli najmniejszej nie mogąc konsyderacji, ponieważ Pan Chyliński tak mawiał że: „kto mnie tak Xciu służy i kto moich rozkazów słucha nigdy honoru, ani zapłaty ode mnie nie weźmie, kiedy nie zechcę" 48 .

${ }^{45}$ W 1746 roku zmarł ojciec Kazimierza, zapisując mu 1000 złotych, podobnie jak jego bratu Stanisławowi. Wykonanie tego zapisu powierzył Józefowi Ossolińskiemu. Szerzej: APK, AS TA, sygn. 110/24, Regestr rzeczy jako bydź powinny różne po zeszłym P. Janie Chylińskim o ojcu naszym spisanym Roku 1746, s. 31-36; sygn. 110/25, s. 11-16.

46 APK, AS TA, sygn. 41/20, s. 3, 10; sygn. 169/7, s. 30-33.

${ }^{47}$ APK, AS TA, sygn. 100/25, Jełowiecki do K. Chylińskiego, Uściług, 5 VII 1746, s. $41-44$.

48 APK, AS TA, sygn. 42/7, s. 41. 
Administratorzy majętności dubieńskiej, konstantynowskiej, baranowskiej i stepańskiej przysyłali mu regularne raporty ze stanu ekonomicznego dóbr oraz dochody uzyskane ze sprzedaży płodów rolnych i produkcji folwarcznej ${ }^{49}$. Niekiedy powiadamiano go o konfliktach, jak w przypadku Zwiahela, gdzie z domów wyrzucono tamtejszych Żydów i informowano o zatargu z poddanymi podstolego kijowskiego, Jana Michała Pruszyńskiego $^{50}$. W kwestii gospodarczej kierowano do stolnika łomżyńskiego i subdelegata oświęcimskiego dezyderaty i prośby, na przykład by wstawił się u księcia za poddanymi, zgnębionymi nieurodzajem:

tak upadli i zrujnowali się, że bez chleba teraz obchodzą z wielką biedą i trudnością ale nad wszystko i siać na następną wiosnę czym nie będą mieli i jakby teraz nie dosiali z wielką by poszła ta wieś ruiną in futurum ${ }^{51}$.

Nadawca błagał o chleb, bydło i zasiewy. Powszechnie skarżono się jednak na Chylińskiego, pełniącego rolę ekonoma generalnego, że żadna asygnacja czy obligacja nie mogą być spełnione bez jego podpisu, mimo woli księcia. Zwróćmy jednak uwagę, że problem zarządu majątkiem ordynacji - jak wykazali w swoich badaniach Andrzej Pośpiech i Wojciech Tygielski - był dwojaki: centralistyczny i decentralistyczny ${ }^{52}$. Magnat sam decydował w sprawach ważnych i drobnych, lecz najczęściej przekazywał kompetencje zaufanemu słudze, rezerwując sobie wyłącznie prawo zmiany decyzji. W praktyce słudzy otrzymywali znaczną swobodę i sami wydawali zarządzenia. Konflikty i nieporozumienia były nieuniknione, zdarzały się wielokrotnie, szczególnie wtedy, kiedy jedna ze stron nie reagowała na

49 APK, AS TA, sygn. 100/22, S. Rychter do K. Chylińskiego, Czekarzewo, 6 X 1746, s. 33-34; sygn. 304/4, J. D. Kuczyński do K. Chylińskiego, Baranów, 1 IX 1746, s. 47-50; sygn. 304/5, S. F. Dąbrowski do K. Chylińskiego, Kulczyny, 13 IX 1747, s. 47-50; A. Przezdziecki do K. Chylińskiego, Konstantynów, 17 IX 1747, s. 73-76.

50 APK, AS TA, sygn. 304/5, A. Wyleżyński do K. Chylińskiego, b. m., 4 IX 1747, s. 59-62.

51 APK, AS TA, sygn. 304/4, K. Orański-Woyna do K. Chylińskiego, Woyków, 29 II 1745 , s. $1-4$.

52 A. Pośpiech, W. Tygielski, Spoteczna rola dworu magnackiego XVII-XVIII wieku, „Przegląd Historyczny” 1978, t. 69, z. 2, s. 218-219. 
nadsyłane listy. Przypomina to żywo problem niejasności podziału władzy w latyfundium Elżbiety z Lubomirskich Sieniawskiej, gdzie „siła panów nad poddanemi, którzy nie wiedzieć kogo mają słuchać i kogo się bać"53.

Ingerencja Chylińskiego nie ograniczała się wyłącznie do zarządu pionem administracyjnym, władał także we dworze. Jako sekretarz księcia miał pełny dostęp do poczty przysyłanej do różnych osób i ekspediowanej z kancelarii księcia. Najczęściej umawiał wizyty Janusza Aleksandra z Lubomirskimi: Józefem, podstolim litewskim, Antonim Benedyktem, starostą kazimierskim, i Stanisławem, podstolim koronnym i starostą sądeckim ${ }^{54}$. Należeli oni nie tylko do najbliższych sąsiadów magnata, ale też głównych powodów w sprawie o alienowanie przez księcia dóbr spornych z majątku ordynackiego, sprzedaż klejnotów i roztrwonienie mobiliów. Chyliński, poza tym, że trzymał zarząd nad korespondencją, dokumentami sądowymi i finansowymi, dodatkowo był depozytariuszem nowin obejmujących sprawy prywatne magnatów ${ }^{55}$. Najczęściej były to wieści dotyczące tematów poruszanych w rozmowach z księciem czy sprawy tyczące rodzinno-majątkowych pozycji rodzin, z którymi Janusz Aleksander prowadził interesy ${ }^{56}$. Pozwalało to Chylińskiemu, jako kanałowi informacyjnemu, w niemałym stopniu dowolnie moderować charakter spotkań i wpływać na działania podejmowane przez ordynata. Zważmy, że wobec wyżej postawionej tezy, jakoby dwór Janusza Aleksandra był „szkołą” dla Chylińskiego, możemy z całą mocą stwierdzić, że była to też przestrzeń towarzyska, pozwalają-

53 Cyt. za: D. Bąkowski-Kois, Zarządcy dóbr Elżbiety Sieniawskiej. Studium z historii mentalności 1704-1726, Kraków 2005, s. 65-66.

54 APK, AS TA, sygn. 304/4, J. Lubomirski do K. Chylińskiego, Łabuń, 21 VII 1746, s. 51-52; A. B. Lubomirski do K. Chylińskiego, Lwów, 18 VI 1747, s. 57-60; sygn. 304/5, S. Lubomirski do K. Chylińskiego, Równe, 8 VIII 1745, s. 1-4; J. Lubomirski do K. Chylińskiego, Łabuń, 21 IX 1746, s. 9-12; S. Lubomirski do K. Chylińskiego, Równe, 31 VIII 1747, s. 25-28; Lubomirski do K. Chylińskiego, b. m., 10 IX 1747, s. 71-74.

55 APK, AS TA, sygn. 304/4, A. Lubomirski do K. Chylińskiego, Połonne, 7 VIII 1747, s. 99-100; sygn. 304/5, J. Karwicki do K. Chylińskiego, Opatów, 11 V 1746, s. $13-16$.

${ }^{56}$ APK, AS TA, sygn. 304/4, A. Lubomirski do K. Chylińskiego, Dubno, 20 IV 1747. 
ca sekretarzowi poznać wielkopański świat i zdobyć upragniony prestiż ${ }^{57}$. Przykładem może być ustawienie wyboru posłów na sejmik gospodarski opatowski, na którym miano wybrać sędziego sandomierskiego i pisarza stężyckiego na urzędy dotąd wakujące ${ }^{58}$. W obawie przed wyborem niekorzystnym dla interesu księcia miecznika, nakazał - dzięki wcześniejszym enuncjacjom - rozdać złoto, pierścionki, konie i zboże jako formę przekupstwa ${ }^{59}$. Obnaża to pasywność i inercję Janusza Aleksandra w kwestii zainteresowania sceną polityczną.

Młodzieńcza inicjacja, miłość patrona, a nade wszystko posłuszeństwo sprawiły, że Chyliński szybko wspiął się na szczyt urzędów dworskich. Była to, jak się okazało, pozorna gwarancja na wypadek odmiany fortuny. Opieka wzbogacona uczuciem spowodowała, że ubogi dotąd szlachcic z klienta przeistoczył się w pośrednika protegującego szlachtę nieposesjonacką przed księciem miecznikiem. „Poufała protekcja”, „łaskawy respekt i adoracja”, "godna obserwancja”, „aplikacja” były zwrotami najczęściej używanym przez klientelę szlachecką. Zabiegali oni najczęściej o służbę dla siebie na dworze księcia, co pozwoliłoby im na osiąganie wymiernych profitów finansowych, a tym samym na egzystencję lub spłatę długów ${ }^{60}$. Niektórzy „panowie bracia”, wzorem rodziców Chylińskiego, chcieli, by ich synowie mogli zyskać stałą służbę i edukację w zamian za wierność i oddanie sprawom Sanguszki ${ }^{61}$. Mniej liczne zwroty zawierały korne prośby o przedłużenie salarium, czyli pensji pobieranej przez służbę dworską ${ }^{62}$, rozstrzygnięcie

57 A. Mączak, Klientela. Nieformalny system wtadzy w Polsce i Europie XVI-XVIII w., Warszawa 2000, s. 292-293.

58 Urzędnicy województwa sandomierskiego XVI-XVIII wieku. Spisy, opr. K. Chłapowski, A. Falniowska-Grabowska, red. A. Gąsiorowski, Kórnik 1993, s. 114, 137.

59 A. Mączak, op. cit., s. 288; APK, AS TA, sygn. 304/4, J. D. Kuczyński do K. Chylińskiego, Baranów, 1 IX 1746, s. 47-50.

${ }^{60}$ APK, AS TA, sygn. 304/4, J. Kobylnicki do K. Chylińskiego, Korzec, 5 XII 1745, s. 9-11; F. Czarnecki do K. Chylińskiego, Kamieniec, 15 IX 1746, s. 39-42; J. Krasicki do K. Chylińskiego, b. m., b. d., s. 69-71; Jełowiecki do K. Chylińskiego, b. m., b. d., s. 73-76; sygn. 304/5, J. Kobylnicki do K. Chylińskiego, b. m., 1 XI 1745, s. 5-8.

${ }^{61}$ APK, AS TA, sygn. 304/4, J. Szaniawski do K. Chylińskiego, b. m., 14 V 1745, s. 17-18; W. Głębski do K. Chylińskiego, Hrycyki, 4 IX 1747, s. 61-64.

${ }^{62}$ APK, AS TA, sygn. 304/4, A. Chrynowski do K. Chylińskiego, Baranów, 6 IX [?.?], s. 85-88; Jan Kanty karmelita bosy do K. Chylińskiego, b. m., b. d., s. 117-120. 
sporu sądowego z nieprzyjaznym sąsiadem ${ }^{63}$, poparcie na wakujący urząd ${ }^{64}$, nadanie arendy ${ }^{65}$, udzielenia kredytu ${ }^{66}$. Niekiedy, choć rzadko, proszono o łaskę i błogosławieństwo księcia dla związku małżeńskiego ${ }^{67}$. Nie miejmy złudzeń, że klienci rekrutowali się wyłącznie spośród drobnych szlacheckich szaraczków. Do grupy piszącej zaliczała się też magnateria. Materiał źródłowy pokazuje, że stolnik łomżyński był wtajemniczony w wielce delikatną sprawę transakcji dóbr klucza klimontowskiego i baranowskiego. Rywalizowali o nie Lubomirscy i Sapiehowie, a podstoli sandomierski, Stanisław Moszyński, obstawał nawet za oddaniem obu kluczy stolnikowej chełmskiej, Annie Sługockiej ${ }^{68}$. Sprawa, wymagająca dyskrecji i rozmów sub rosa, została w końcu rozstrzygnięta na korzyść Lubomirskich.

Pozytywne rozstrzygnięcie spraw skutkowało nadsyłanymi do Chylińskiego podziękowaniami, prezentami oraz zaproszeniami np. na zabawy zapustne $^{69}$. Nie był to pusty gest, a forma stałego przypomnienia o wdzięczności. Sądzono, że dzięki temu patron zachowa w swej pamięci klienta i zwróci się ponownie do niego z misją.

63 APK, AS TA, sygn. 304/4, F. Śleszyński do K. Chylińskiego, Równe, 27 VIII 1745, s. 23-26; A. Kopycki do K. Chylińskiego, b. m., 4 IX 1746, s. 81-84; sygn. 304/5, J. A. Kochański do K. Chylińskiego, Przeworsk, 12 VII 1747, s. 85-88.

${ }^{64}$ APK, AS TA, sygn. 304/4, A. Morski do K. Chylińskiego, b. m., b. d., s. 105.

${ }^{65}$ APK, AS TA, sygn. 304/4, N.N. do K. Chylińskiego, b. m., 18 I 1746, s. $143-$ -144; sygn. 304/5, K. Sapieha do K. Chylińskiego, Lwów, 19 I 1747, s. 29-32.

${ }^{66}$ APK, AS TA, sygn. 304/5, J. A. Kochański do K. Chylińskiego, Boguchwała, 24 VI 1747, s. 51-54.

${ }^{67}$ APK, AS TA, sygn. 304/5, Malszycki do K. Chylińskiego, Michałowice, 19 I 1747 , s. 103-106.

68 APK, AS TA, sygn. 304/4, F. J. Kossowski do K. Chylińskiego, Sandomierz, 15 VII 1745, s. 13-16; A. Z. Czyżowski do K. Chylińskiego, b. m., 12 V 1745, s. 27 -30; A. Lubomirski do K. Chylińskiego, Dubno, 20 IV 1747, s. 89-92; K. Sapieha do K. Chylińskiego, Werbkowice, 17 XI 1746, s. 145-146; sygn. 304/5, A. Lubomirski do K. Chylińskiego, Przeworsk, 26 VII 1747, s. 107-110.

${ }^{69}$ APK, AS TA, sygn. 304/4, B. Brodowski do K. Chylińskiego, b. m., 9 XI 1745, s. 5-8; A. Drzewiecki do K. Chylińskiego, Krzemieniec, 29 VI 1746, s. 19-22; K. Sapieha do K. Chylińskiego, Werbkowice, 28 XI 1746, s. 77-78; J. Kobylnicki do K. Chylińskiego, Korzec, 22 III 1745, s. 35-38; F. Czarnecki do K. Chylińskiego, Kamieniec, 15 IX 1746, s. 39-42; F. Krasicki do K. Chylińskiego, Nadarzyn, 17 IX 1745, s. 129-132; J. Czaplic do K. Chylińskiego, Lwów, 18 II 1747, s. 147-150. 
Książęcy sekretarz nie zapomniał o pozyskiwaniu łask dla siebie i swojej rodziny. Taki wymiar miała więź spajająca patrona z klientem niezależnie od tego, czy łączyły ich relacje głębsze, na przykład miłość. Jędrzej Kitowicz, oceniając związek Janusza Aleksandra z Kazimierzem Chylińskim, zapisał w swym dziele następujące sformułowanie, które bardzo trafnie oddaje jego charakter:

Obmiotem pasji jego był jaki hoży młodzieniec, na którego wysypywał niemal wszystkie skarby swoje; ten władał sercem jego, odzierał księcia z pieniędzy z klejnotów i z tego wszystkiego, co mu się podobało; nic nie powściągało faworyta od takowych grabieży tylko jedna bojaźń podwrotu szczęścia, na niebezpiecznych fundamentach stojącego ${ }^{70}$.

Zdanie to potwierdza materiał źródłowy. Miecznik litewski wydawał Chylińskiemu asygnacje na różne kwoty, czasami uzależniał je od woli okaziciela $^{71}$. Stolnik łomżyński kupował za nie bogate szaty wykonane z sukna francuskiego i adamaszku² ${ }^{72}$. Dzięki swej pozycji zdołał finansowo zabezpieczyć swą niezbyt bogatą rodzinę. Poparcie Janusza Aleksandra Sanguszki sprawiło, że w 1745 roku w imieniu siostry Zofii, która powtórnie została wdową, zawarł umowę ze Stanisławem Moszyńskim na wydanie jej posagu obejmującego dobra Jurkowice i Witowice wraz z poddanymi ${ }^{73}$. Dalszemu krewnemu, Sewerynowi Chylińskiemu, wyjednał u księcia urząd gubernatora twierdzy dubieńskiej. Niespodziewana śmierć w wyniku gorączki i napadu paroksyzmu w drodze z Tomaszowa pokrzyżowała jednak te pla$n y^{74}$. Na liście obdarowanych znalazł się też brat Kazimierza, Stanisław. Ten

70 J. Kitowicz, Pamiętniki, czyli Historia Polska, wyd. P. Matuszewska, Z. Lewinówna, Warszawa 2005, s. 63.

71 APK, AS TA, sygn. 40/16, J. A. Sanguszko do K. Chylińskiego, Baranów, 14 I 1745, s. 3; sygn. 100/25, J. A. Sanguszko do K. Chylińskiego, Dubno, 22 IX 1747, s. 57.

72 APK, AS TA, sygn. 100/26, s. 7. Zakupy poczynione u kupca opatowskiego, Abramowskiego, opiewały na sumę 226 złotych polskich 10 groszy.

73 APK, AS TA, sygn. 100/25, s. 29.

74 APK, AS TA, sygn. 304/4, J. Brodzki do K. Chylińskiego, Zielonka, 10 VII 1747, s. 101-104. Innym przykładem dalekiego krewnego był Przybyszewski, który przez wzgląd 
drugi w swoim liście z 1747 roku gorąco apelował do sekretarza książęcego, by jak najszybciej wystarał się o konsens i akty intromisji do wsi w kluczach bazalskim i glińskim, bo jak narzekał:

na sądach ja się nie pomieszczę, bo tam będą potentatores to ci zaraz uchwycą choćby kto był odsądzony ${ }^{75}$.

Zachłanność Kazimierza i wyraźna roszczeniowość wobec księcia przywiodły go do zguby. Plany zakupu wsi w województwie sandomierskim zostały wykorzystane przez wrogów Chylińskiego, chcących pewnie zemścić się na wszechwładnym słudze lub ukarać sodomitę bez naruszania honoru księcia. Zamysł taki pojawił się we wrześniu 1747 roku, o czym wspomina wyraźnie Jan Brodzki do anonimowego adresata ${ }^{76}$. Prosił, by ten wysondował rynek nieruchomości i odnalazł właściwego kontrahenta, a następnie „nastręczył” Chylińskiemu sprzedawcę

i insze które możesz wiedzieć dobra i tę wieś co to Pakosławskich wioska, opisz jako donację od kogo będzie należało i z kim i które dobra mówić i czynić będzie należało ${ }^{77}$.

Motorem intrygi uknutej celem wyeliminowania Chylińskiego z dworu książęcego był ojciec Janusza Aleksandra, Paweł Karol Sanguszko:

na pokrewieństwo prosił Chylińskiego o wstawienie się u księcia w sprawie oddania mu karczmy, vide: APK, AS TA, sygn. 100/25, Przybyszewski do K. Chylińskiego, Hrehorówka, 21 IX 1747, s. 45-48.

75 APK, AS TA, sygn. 304/5, S. Chyliński do K. Chylińskiego, Radziechów, 7 VII 1747, s. 24.

${ }^{76}$ Trzeba w tym miejscu uściślić, że Brodzki był zadłużony u Chylińskiego i być może to skłoniło go do współpracy z Pawłem Karolem Sanguszką, zob.: APK. AS TA, sygn. 100/25, J. Brodzki do K. Chylińskiego, Dubno, 12 VIII 1745, s. 15.

77 APK, AS TA, sygn. 100/22, Brodzki do NN, Zielonka, 15 IX 1747, s. 160. Nie powiodła się próba ostrzeżenia Chylińskiego przed planowaną przeciw niemu akcją, zob.: APK, AS TA, sygn. 42/7, J. Gostyński do K. Chylińskiego, Dubno, 20 IX 1747, s. 3-5. 
To musi się stać dla interesu JM Xięcia i skutek ad vota jego, sam na się to biorę jak upewniłem tak dotrzymam bom ja na zawsze Twój sługa kochany Dobrodzieju tedy do niego i do mnie jak najprędzej przez tego posłańca napisz ${ }^{78}$.

Dowodem „zbrodni” stała się suma 40000 złotych, za którą Chyliński miał kupić majątek ziemski, zdeponowana w skrzyni z pieczęciami marszałka nadwornego litewskiego. Sepet Chylińskiego zarekwirowany w Kolbuszowej zawierał, poza gotówką, galanterię. Paweł Karol Sanguszko nakazał przywieźć owo corpus delicti do Baranowa jako świadectwo niecnych postępków i machinacji sekretarza ${ }^{79}$. Oczywiście był to jedynie pretekst do uwięzienia Chylińskiego. Powodów jego upadku było znacznie więcej.

Marszałek nadworny litewski dążył do pozbycia się Chylińskiego, mając wzgląd na rozpadające się małżeństwo Janusza Aleksandra z młodziutką Konstancją z Denhoffów. Związek zawarty w sierpniu 1731 roku z córką Stanisława Denhoffa, hetmana polnego litewskiego i wojewody połockiego, oraz Joanny z Przebendowskich z góry skazany był na niepowodzenie. Janusz Aleksander zaniedbywał swoją małżonkę, pozostawiając ją samą w pałacu w Baranowie. Spotykał się z nią jedynie rankiem i wieczorami. Młodzi nie dzielili ze sobą łoża, a zatem nic nie wskazywało, by mogli spłodzić potomstwo - przyszłych dziedziców ogromnej fortuny. Naturalnie budziło to obawy Pawła Karola, że dobra ordynackie przejdą w obce ręce. Miecznik litewski jeszcze za życia ojca czynił starania o unieważnienie małżeństwa, dając za powód zawarcie sakramentu pod przymusem i nieskonsumowanie związku $^{80}$. Konstancja niejednokrotnie ubolewała, że jej mąż woli spędzać

${ }^{78}$ Ibidem, s. 161.

79 APK, AS TA, sygn. 40/16, [Zeznanie Zbigniewa Piotrowskiego z odbioru sepetu], Kolbuszowa, 20 I 1748, s. 7.

${ }^{80}$ W 1740 roku wysiłki zmierzające do unieważnienia małżeństwa zostały przekreślone przez Pawła Karola. Śmierć marszałka nadwornego litewskiego w 1750 r. pozwoliła Januszowi Aleksandrowi wskrzesić projekt i zgłosić pozew do konsystorza duchownego w Łucku. W tym celu sporządzono dziewięciopunktowy memoriał uzasadniający rozpad małżeństwa. Spodziewanego unieważnienia jednak nie uzyskał, a Konstancja zamieszkała na dworze macochy księcia, Barbary z Duninów Sanguszkowej. Dopiero w 1775 r., po śmierci księcia, wyszła ponownie za mąż za Józefa Rogalińskiego, który, podobnie jak Janusz Aleksander, okazał się hulaką trwoniącym majątek. Wobec tego błędna jest informa- 
czas poza domem niż z nią. Ojciec utracjusza chciał za wszelką cenę przerwać romans syna z Kazimierzem Chylińskim, mając nadzieję, że zmieni to stosunek Janusza Aleksandra do żony i zapobiegnie ludzkim obmowom ${ }^{81}$. Niepomyślny rozwój wypadków był zresztą realny, a przyczyny tego Paweł Karol dostrzegał w charakterze syna, który gotów był obdarzać swoich amantów rozlicznymi bogactwami. „Ślepego” na zakusy kochanków i bezwolnego księcia ojciec pouczał słowami:

zważaj mój kochany synu jak cię te koligacje z Fortuny ujmują, kiedy pachołków sobie w dworze czynisz w Stepaniu, trzeci w Konstantynowie, czwarty przy boku, z którymi przyjdą w pewne czasy do Fortuny owi Panowie będą, a ty mój Kochany synu ich chłopem i pachołkiem i tym Ciebie przestrzegę i miej nad sobą własnym miłosierdzie, kiedy ze wszystkiego drwisz. Nie odmieniaj za tym synowskiego affektu i byś mnie prawdy pisał, abyś po tym nie powiedział że nie było doma kogo przestrzec $^{82}$.

Niewątpliwie Sanguszko próbował bronić honoru nie tylko syna, ale i swego. Nie chciał jak dawniej patrzeć przez palce na wybryki syna ${ }^{83}$. Wiedział, że okoliczna szlachta szepcze o związku Janusza Aleksandra z Kazimierzem Chylińskim. Miał pewność, że omnipotencja Chylińskiego

cja Marcina Matuszewicza, jakoby Janusz Aleksander, wspierany przez Michała Kazimierza Radziwiłła „Rybeńkę”, starał się w 1761 r. o rękę owdowiałej podkanclerzyny litewskiej Sapieżyny. Więcej zob.: APK, AS TA, sygn. 377/9, K. z Denhoffów Sanguszkowa do B. z Duninów Sanguszkowej, b. m. i d., s. 7; sygn. 481/2, Domański do J. A. Sanguszki, Dąbrowica, 18 VI 1740; M. Przybyszewski do Sierawskiego, Lublin 3 VIII 1751, s. 3; Particulatus libellus ex parte Celsissimi Ianusii Alexandri in Biały Kamień etc. etc. sive rationes non cohabitationes cum Cel. Constantia Denhoffowa Sanguszkowa principissa pretensa consorte sua, in ordine ad expediendam comissionem cum inquisitionem, s. 9; Gorczyński do NN, Dubno, 8 IX 1751, s. 11; M. Matuszewicz, Diariusz życia mego 1758-1764, t. 2, wyd. B. Królikowski, Warszawa 1986, s. 169; M. Czeppe, R. Marcinek, Sanguszkowa $z$ Denhoffów 2voto Rogalińska Konstancja Kolumba, [w:] PSB, t. 34/3, s. 523-524; I. Kulesza-Woroniecka, Rozwody $w$ rodzinach magnackich $w$ Polsce XVI-XVIII wieku, Poznań-Wrocław 2003, s. 35, 118; A. Jakuboszczak, op. cit., s. 113, 131, 158.

81 APK, AS TA, sygn. 100/22, Sułkowski do K. Chylińskiego, b. m., b. d., s. 189-190.

${ }^{82}$ APK, AS TA, sygn. 44/3, P. K. Sanguszko do J. A. Sanguszki, Zasław, 13 V 1747, s. $5-7$.

83 J. Kitowicz, op. cit., s. 65. 
przybrała zbyt duże rozmiary, a jego zachowanie uchybiało przyzwoitości dworu. Sekretarzowi wypominano apodyktyczny styl bycia, wręcz wynoszący się ponad stan:

Bez wszelkiego respektu dla Pana przy gościach publicznie J. O. Xcia Jmci ostatniemi łajał słowy, tak dalece, że jednego czasu w pokojach wejrzawszy na portrety wymówił słowa: „Gdyby ten Xiążę Ostrogski malowany z martwych powstał pewnieby Xciu Miecznikowi sto rózeg wpięty, a sto rózek w tyłek dać rozkazał" ${ }^{84}$.

Napastliwość Chylińskiego owocowała nie tylko kłótniami, groźbami nasłania Kozaków dla rabunku, ale i okaleczenia czy nawet uśmiercenia Janusza Aleksandra. Materialnym dowodem słów miały być zioła, które znaleziono u Chylińskiego, i zeznania znachorki, że są one trujące ${ }^{85}$. Wydaje się, że książę dawał przyzwolenie na tego typu postępki i nie okazał swego niezadowolenia. Brak szacunku i wynoszenie się względem kochanka pozwalały widzieć związek w kategoriach pasożytnictwa pozbawionego uczuć wyższych. Nieporozumienia i waśnie wywoływane przez księcia afiszującego się ze swym kochankiem spowodowane były niewiernością Chylińskiego. Do grona kochanków sekretarza należał także inny szlachetnie urodzony, podczaszy nowogródzki, Jan Wincenty Siedlecki, który nie ustawał w swych miłosnych zapewnieniach $^{86}$. Przepraszając za zwłokę w przyjeździe do Dubna, pisał:

dlategom i nie miał sposobności odezwać się memu kochanemu Dobrodziejowi z tym sercem, które wiadome ci jest że szczerze i prawdziwie Ciebie kochające ale i Twoja nie łaska przyznasz mnie wspomnieć o swoim słudze o czym ja chcę być punktualny w mojej dla Ciebie przyjaźni póki cię sam osobiście nie ucałuję presentibus tenerime ściskam. Bądź jednostajnie łaskaw proszę kochaj kochającego Ciebie serdecznie a bądź zdrów na przywitanie Pana ${ }^{87}$.

${ }^{84}$ APK, AS TA, sygn. 42/7, s. 41-42.

85 APK, AS TA, sygn. 42/7, s. 42; Konotata dobrowolne z rewizyji sporządzone d. 6 V 1748, s. 43.

${ }^{86}$ Urzędnicy województwa kijowskiego i czernichowskiego XV-XVIII wieku. Spisy, red. E. Janas, W. Kłaczewski, Kórnik 2002, s. 226-227.

${ }^{87}$ APK, AS TA, sygn. 304/5, J. W. Siedlecki do K. Chylińskiego, b. m., b. d., s. $121-124$. 
Miłosny trójkąt budził oburzenie, co więcej, stał się powodem rozpadu związku z Januszem Aleksandrem. Wiedza o nim została wykorzystana przez sekretnych kochanków miecznika litewskiego, Urbankowskiego i Krzysztofa Szydłowskiego. Zdaniem Stanisława Rychtera właśnie oni rozdmuchali sprawę bogactw Chylińskiego, ukazując go jako zdziercę i defraudatora majątku Sanguszków ${ }^{88}$. Kilka lat po uwięzieniu Chylińskiego miecznik smoleński, Krzysztof Szydłowski, zajął miejsce stolnika łomżyńskiego i znalazł się na liście obdarowanych podczas transakcji kolbuszowskiej. Marcin Matuszewski wypomniał z odrazą, że ten „amant i faworyt” otrzymał miasto Koźmin i 17 wsi ${ }^{89}$. Chyliński zdawał sobie sprawę ze zmowy i czuł osaczenie. Zaklinał się, że nigdy nie wziął wymienianej sumy, którą w rzeczywistości przeznaczył na opłatę dworu księcia:

wszakże nie cały Wołyń jak za Jaśnie Pana Mego w Dubnie ujmowałem się honor i zapewne żebym był niesławy i JM p. Mokronowski pewnie by szwank J. Mści Pana mego otrzymał aby tylo ludzi J. Pana, któż się za jego honor ujął jeżeli nie ja. Szukali różni zemsty szansy, bom ja gorszy żem nie dał JM Pana Dobrodzieja honoru i substancji brać teraz otrzymali to czego sobie życzyli ${ }^{90}$.

Finałem wydarzeń i romansu trwającego przeszło kilka lat stało się uwięzienie Kazimierza Chylińskiego w gdańskim cekhauzie ${ }^{91}$. Marszałek nadworny litewski zamknął nadto syna w dubieńskiej twierdzy i nakazał mu „wydać komendę na piśmie nad garnizonem dubieneckim i rząd

${ }^{88}$ APK, AS TA, sygn. 100/22, S. Rychter do K. Chylińskiego, b. m. 4 X 1747, s. $145-146$.

${ }^{89}$ M. Matuszewicz, op. cit., t. 1, s. 433. Szydłowski, będąc starostą uszyckim, pojawił się później jako beneficjent łask księcia Marcina Jerzego Lubomirskiego, więcej zob.: Biblioteka Jagiellońska w Krakowie, sygn. 5146, M. Modzelewski, Wrażenia z podróży po Radomskiem, k. 101-102.

90 APK, AS TA, sygn. 42/7, K. Chyliński do J. Chylińskiego, 22 XI [1749?], s. 17-18.

91 APK, AS TA, sygn. 40/16, Copia literrarum Supremi Regni Cancellari ad Illu et Praeclarissimus Magistratum Gedanensem, Gedaniae 6 Aprilis 1748, s. 19-20; sygn. 100/22, s. 171-172; sygn. 253/4, J. Małachowski do P. K. Sanguszki, Warszawa, 19 XII 1748, s. 143-146; sygn. 259/8, J. Małachowski do P. K. Sanguszki, Końskie, 25 III 1749, s. $27-30$. 
nad całym dworem"92. Kazimierzowi Chylińskiemu formalnie zarzucono malwersacje i sprzeniewierzenie pieniędzy, lecz wiadomo było, że chodzi o izolację od Janusza Aleksandra. Z pomocą Pawłowi Karolowi przyszedł Jan Małachowski, kanclerz wielki koronny, który wydał nakaz aresztowania. W kwietniu 1748 roku Chyliński został przewieziony do Gdańska i umieszczony w domu poprawczym, tzw. domus correctionis. Regulamin tego miejsca przewidywał ciężką pracę resocjalizacyjną, która miała człowieka oduczyć zła i uszlachetnić jego charakter ${ }^{93}$. Julian Chyliński tak komentował uwięzienie brata:

pod wartą ludzi swoich nadwornych wziął i onego cum summa pospositione equalitatis przydawszy kilkadziesiąt swoich dragoniej i ludzi lekkich chorągwi cum secundonato patrzących przez tyle województwa, ziem i powiatów kazawszy do dóbr swoich Łąka nazwanych zaprowadził, dotąd w ścisłym więzieniu zatrzymuje [...] a żołnierza ze wszystką bronią i opatrznością na każdą noc ordynuje ${ }^{94}$.

Subdelagat oświęcimski i stolnik łomżyński przebywał w strasznych warunkach i wiele wskazuje na to, że był torturowany i bity. Rany zadane mu w czasie pobytu w więzieniu sprawiły, że nie mógł się poruszać i zmuszony był przebywać w łóżku. Nie pomagała mu opieka medyczna nadesłana od kanclerza Małachowskiego:

niewinnie przy strasznym kalistwie moim i głodzie poniesionym już na drugie półroku jak nie ustając za łaską pod ręką medyka, którego mam w ordynansie JMści Pana Kanclerza W. X i Dobrodzieja nadanego, który jako uważam, że musi mnie odstąpić, gdyż tak strasznemu defektowi pomóc nie może [...] z takim charakterem piszę, gdyż leżący bo już niedziel jest trzydzieści pięć jak nie wstaję z łóżka dla mego tak strasznego kalistwa, z którego jako uważam że muszę umierać jeżeli mnie Bóg nie uratuje ${ }^{95}$.

92 APK, AS TA, sygn. 237/8, J. A. Sanguszko do P. K. Sanguszki, Dubno, 29 V 1748, s. 44-45; J. Kitowicz, op. cit., s. 64.

${ }^{3}$ M. Bogucka, Dom Pracy Przymusowej w Gdańsku w XVII w., „Kwartalnik Historii Kultury Materialnej” 1986, t. 34, nr 2, s. 265-268.

${ }_{94}$ APK, AS TA, sygn. 40/16, s. 15-16.

95 APK, AS TA, sygn. 262/12, K. Chyliński do B. z Duninów Sanguszkowej, [Gdańsk], 26 V 1752, s. 33-36. 
Obraz ten pozwala sądzić, że intencją Pawła Karola Sanguszki było nie tylko odizolowanie obu mężczyzn i zastraszenie Chylińskiego, lecz też jego zgładzenie. Zgodnie z polskim prawem kontakty homoseksualne kwalifikowane był jako czyn zagrożony śmiercią. Taki artykuł miał swoje uzasadnienie w kodyfikacji Bartłomieja Groickiego pochodzącej z 1559 roku, w nawiązaniu do wydanego kilkanaście lat wcześniej Constitutio Criminales Carolina autorstwa cesarza Karola V:

Gdzieby kto takowy naleziony był, żeby abo z bydlęciem abo chłop z chłopem przeciw przyrodzeniu sprawę miał, takowi mają być na gardle skarani, a według obyczaju mają być spaleni, bez wszelkiego zmiłowania i łaski ponieważ ten haniebny i sromotny grzech jest, ma być srodze karan ${ }^{96}$.

Strach i lęk zmobilizowały jednak Chylińskiego do działania na rzecz uwolnienia. Pomocą służył przez cały ten okres Julian Chyliński, który na roczkach ziemskich kamienieckich wystosował oficjalną manifestację przeciwko czynowi księcia marszałka nadwornego ${ }^{97}$. Domagał się uwolnienia brata, dowodząc, że jego uwięzienie narusza nietykalność osobistą i prawo gwarantujące sprawiedliwy proces sądowy ${ }^{98}$. Sam nie mógł jednak nic zdziałać. Za radą Kazimierza zaczął gromadzić głosy członków rodziny i szlachty sandomierskiej, a nawet zabiegać u hetmana polnego koronnego i wojewody krakowskiego, Jana Klemensa Branickiego, oraz biskupa krakowskiego, Kajetana Sołtyka, o protest przeciw Sanguszce ${ }^{99}$. Gorąca atmosfera rodziła sprzeczne doniesienia o losie Chylińskiego z dala od pańskiego salonu, na peryferiach:

96 B. Groicki, Artykuty prawa majdeburskiego. Postępek sądów okoto karania na gardle. Ustawa ptacej u sądów, Warszawa 1954, s. 153.

${ }_{97}$ APK, AS TA, sygn. 40/16, s. 11-13; sygn. 44/15, s. 1-2.

${ }_{98}$ Paweł Karol Sanguszko zamierzał w związku z tym udowodnić Chylińskiemu nieprawdziwe szlachectwo i sondował jego krewnych, czy poprą ten argument, zob.: APK, AS TA, sygn. 100/22, Sendzimir do P. K. Sanguszki, Okocim, 11 IX 1747, s. 153-154.

99 APK, AS TA, sygn. 41/20, K. Chyliński do J. Chylińskiego, [Gdańsk], 22 XI [1749?], s. 17-20; J. Chyliński do K. Chylińskiego, Międzyrzecz, 12 II 1749, s. 47-50; sygn. 100/22, Sułkowski do [K. Chylińskiego], b. m., b. d., s. 187-190. 
O Jm Panu Chylińskim co tam jest pewnego i co z nim zrobią także wielce upraszam kazać mi doskonale donieść bo tu u nas różne, którym trudno wierzyć wieści i opinie co z nim nastąpi miało [...] Tu już nowe nastąpiło ministerium i porządki takie jak przeszłego, co się z nim stanie czas pokaże, o przeszłym nieraz żeśmy mówili z Jmścią xiędzem Tokarzewskim WM Panem także przed czasem że się to z nim stać musi przy jego appsolutności aż tak się spełniło z czego tu wszyscy kontenci ${ }^{100}$.

Pomoc Chylińskiemu starał się też okazać Janusz Aleksander, pozostający „pod ojcowskim kluczem”. Nie dość, że zaklinał ojca, by nie wszczynał dochodzenia przeciw Kazimierzowi, to wydał manifestację zakazującą nakładania sekwestru na majątek Chylińskiego ${ }^{101}$. Więzień gotów był nawet prosić Pawła Karola Sanguszkę o darowanie krzywd i łaskę ${ }^{102}$. Wolność i możliwość ratunku przyszła jednakże ze strony macochy Janusza Aleksandra, Barbary z Duninów Sanguszkowej. Znana była ona ze swej pobożności i głębokiej formacji duchowej. Agnieszka Jakuboszczak, analizując religijność księżny, wskazuje, że gorliwość praktyk umiała połączyć z wiarą w Bożą pomoc i miłosierdzie ${ }^{103}$. Chyliński, niezależnie od tego, jakie męki cierpiał, podkreślił w swym wylewnym liście rolę Boga jako jedynego Sędziego:

Bóg mój sam na mnie i każdemu się zdał, jako na mego Pana i Stwórcę. Wie Bóg co czyni ze mną mnie zaś należy abyśmy jako prawdziwym robak Pański konferował się z wolą Jego Pańską i serca J. O. W. Mśc Pani Dobrodziejki Mojej błagał ${ }^{104}$.

List skierowany do księżnej odniósł skutek i Chyliński za jej wstawiennictwem opuścił więzienie. Zwrócić należy także uwagę, że po śmierci Pawła

100 APK, AS TA, sygn. 100/22, S. Rychter do ks. Staniewskiego, scholastyka opatowskiego, proboszcza baranowskiego i bialskiego, Dubno, 25 X 1748, s. 147-148; Kownacki do NN, b. m., b. d., s. 191-194.

101 APK, AS TA, sygn. 40/16, s. 1-2; sygn. 40/17, J. A. Sanguszko do P. K. Sanguszki, Dubno, 4 VI 1748, s. 9.

102 APK, AS TA, sygn. 100/22, K. Chyliński do A. Kochanowskiego, [Gdańsk], b. d., s. 197.

103 A. Jakuboszczak, op. cit., s. 56-59.

104 APK, AS TA, sygn. 262/12, K. Chyliński do B. z Duninów Sanguszkowej, [Gdańsk], 26 V 1752, s. 34. 
Karola Sanguszki (zm. 1750), wdowa po nim musiała zmierzyć się z trudnościami $\mathrm{w}$ administracji rozległymi dobrami oraz z uporządkowaniem spraw skarbowych. Chyliński, jako doświadczony w obu materiach, mógł służyć księżnej praktyczną radą i wsparciem. W związku z tym w latach sześćdziesiątych XVIII wieku Kazimierz Chyliński pojawił się w roli zarządcy i sługi księżnej przy budowie jej najwspanialszej rezydencji w Zasławiu. Prace rozpoczęte pod kierunkiem Pawła Fontany zmierzały do połączenia starego i nowego pałacu za pomocą dziedzińca, który okalały dwa skrzydła korytarzy zamknięte bramami ${ }^{105}$. Chyliński pojawił się w ostatniej fazie robót nadzorowanych przez Barbarę. Odpowiedzialny był za sprowadzenie drewna, zamówienie mebli, prace wykończeniowe w pokojach, naprawy cieknącego zimą dachu, prace malarskie, zakup barwy dla służby i lustrację mobiliów ${ }^{106}$. Z tego powodu schorowany stolnik łomżyński, którym opiekował się turecki lekarz, popadał w liczne konflikty z murgrabią zasławskim oraz pannami z fraucymeru księżnej. Swoją służbę zakończył dwadzieścia lat później u wojewody wołyńskiego księcia Hieronima Janusza, od którego w 1787 roku domagał się wypłacenia 5000 złotych $^{107}$.

Reasumując rozważania dotyczące związku zakazanego ukazanego w tym artykule, pragnę wskazać, że w omawianym okresie miłość miała różne oblicza. Januszowi Aleksandrowi i Kazimierzowi Chylińskiemu przypisać możemy wzajemną fascynację i wspólne afiszowanie się, od czego ponoć nie stronili. $Z$ czasem relacja przeistoczyła się w transakcję handlową

105 O rezydencji i pracach nad nią: R. Aftanazy, Zastaw, [w:] Dzieje rezydencji na dawnych kresach Rzeczypospolitej, t. 5, Województwo wotyńskie, Wrocław 1994, s. 132; J. Skrabski, Patac Sanguszków w Zastawiu, „Przegląd Wschodni” 2002, t. 4, z. 3 (27), s. 1169-1178; idem, Organizacja plac budowlanych i artystycznych na dworze Pawta Karola i Barbary Sanguszków, [w:] Wokót Sanguszków..., s. 147-151; A. Jakuboszczak, op. cit., s. 123-124.

106 APK, AS TA, sygn. 265/4, K. Chyliński do B. z Duninów Sanguszkowej Zasław, 4 VII 1769, s. 105-107; K. Chyliński do B. z Duninów Sanguszkowej, Zasław, 24 I 1763, s. 129-132; sygn. 288/3, K. Chyliński do B. z Duninów Sanguszkowej, Zasław, 13 XII 1762, s. 125-128.

107 APK, AS TA, sygn. 273/1, K. Chyliński do H. J. Sanguszki, b. m., 17 IV 1787, s. 87-88; K. Chyliński do H. J. Sanguszki, Zasław, 6 V 1787, s. 89-90. Być może jest to też orientacyjna data śmierci Chylińskiego. 
i naznaczona była rysem zwykłych stosunków łączących patrona z klientem. Chyliński, dostrzegając pasywność i lenistwo swego partnera, postanowił zdobyć majątek. Dzięki temu wzbogacił się nie tylko on sam, ale też jego rodzina i zaprzyjaźniona szlachta. Epistolografia demaskująca związek i jego intymne podłoże pokazuje nam jednak, że Chyliński na swój sposób kochał Janusza Aleksandra. Uwięziony i zgnębiony zdobył się bowiem na takie wyznanie:

Jednakże ja kocham WXMść Dobrodzieja mym sercem i affektem, którym pierwej kochałem i póki życia mego kochać nie przestanę, byłeś WXMść Dobrodziej tego ciężkiego wroga tak pięknym sercem, któregom niegodzien kochać, któregom zaniechał i jego oddalił, ale cóż kiedy WXMśći Dobrodziej o tym nie myślisz. Cokolwiek serce i affektu Pańskiego mieć dla siebie upraszam WXMść Dobrodzieja abyś WXMść Dobrodziej nie chciał dać uczynić mi krzywdy [...] Tym zaś kończę póki tchu we mnie jesteś i będziesz całym sercem prawdziwie kochającym WXMść Dobrodziejem ${ }^{108}$.

Pytanie, ile było prawdy w tym przypływie emocji, a ile koniunkturalizmu, pozostaje otwarte do dalszej dyskusji. Miecznik litewski a następnie marszałek nadworny po związku z Chylińskim

nie miał faworyta jawnego i kosztownego jak przed tym nastraszeniem tylko sekretnych. Ale po śmierci ojca [tj. Pawła Karola Sanguszki w 1750 roku - J. P.] znowu ich miewał utrzymując w takiej figurze jak pierwszych, w czym miał gust zaślepiony; wyjąwszy trybunał, któremu faworyta, w Dubnie zostawionego, nie pokazał ${ }^{109}$.

Książęce brewerie spowodowały upadek jego wizerunku zarówno w oczach cudzoziemców, jak i krajan ${ }^{110}$. Wątpliwa konduita Janusza Aleksandra pozwalała sądzić powszechnie, że zaprzepaścił przedłużenie rodu Sanguszków. Smutną konstatacją wynikającą z losów pary jest to, że ma-

108 APK, AS TA, sygn. 100/22, [K. Chyliński] do [J. A. Sanguszki], [Gdańsk], b. d., s. 199. O queer-epistolografii więcej, zob.: P. Oczko, op. cit., s. 42-47.

109 J. Kitowicz, op. cit., s. 65.

110 Ibidem, s. 64; A. Jakuboszczak, op. cit., s. 32. 
gnat homoseksualista mimo wszystko pozostał magnatem, natomiast zwykły szlachcic, mający podobne inklinacje, oceniany był przede wszystkim przez pryzmat tego, że był homoseksualistą.

\section{The Romance between Prince Janusz Aleksander Sanguszko and his Secretary Kazimierz Chylinski}

\section{(SUMMARY)}

This article is concerned with the seldomly studied topic of the relationship between the successor to the Ostrogski estate, Janusz Aleksander Sanguszko, and his courtier Kazimierz Chyliński. While a queer history approach has been taken, this article is not limited to the examination of the two men's relationship. Instead, the affair is contextualised against the backdrop of customs in pre-partition Poland where homosexual behaviour was condemned in equal measure in public opinion and through church ordinances. The relationship between Sanguszko and Chylinski was defined from the outset by inequality in rank, wealth, education and influence. Eventually, Chyliński's increasing prestige allowed him to gain control over the adminstration of business in the territory, influence several members, act as an intermediary between magnates and as the representative of minor noblemen and to influence considerably Janusz Aleksander Sanguszko's decision-making. It was this economic and political power which attracted the jealousy of Sanguszko's courtiers and the regional nobility and finally lead to Chyliński's downfall as the result of a conspiracy planned by Sanguszko's father, Paweł Karol.

Jarosław Pietrzak
doktorant w Instytucie Historii Uniwersytetu Lódzkiego
jaroslawpietrzak777@gmail.com

